๑Т. П. Андрійчук, А. Я. Сенчук, Д. А. Мартинова

ПВНЗ «Київсъкий медичний університет»

\title{
ДІАГНОСТИКА ТА КОРЕКЦІЯ МАГНІЕВОГО ДЕФІЦИТУ У ВАГІТНИХ ІЗ ОБТЯЖЕНИМ ГІНЕКОЛОГІЧНИМ АНАМНЕЗОМ
}

Мета дослідження - виокремлення пацієнток із клінічними ознаками десріциту магнію серед вагітних із групи ризику розвитку прееклампсії і вивчення есрективності застосування в них препаратів магнію для просрілактики прееклампсії.

Матеріали та методи. Нами здійснені обстеження і комплексна пероральна магнієва профрілактика пізнього гестозу у 100 вагітних (I група) із групи ризику виникнення цього ускладнення вагітності. Результати порівнювали із даними спостереження за 50-ма вагітними (II група) з групи ризику виникнення прееклампсії, яким до профілактичного комплексу пероральні препарати магнію не додавали. Контрольну групу (КГ) склали 50 здорових жінок із фізіологічним перебігом вагітності. Наявність дефіциту магнію визначали за результатами вивчення даних опитування, зафріксованих у розробленій нами анкеті для дослідження дефіциту магнію у вагітних. Магнієву монопрофрілактику прееклампсії здійснювали такими препаратами:

1. Магнію оксид легкий 342 мг і магнію карбонат легкий 670 мг, що відповідає 365 мг іонів Mg $^{++}$- по 1 шипучій таблетці на добу переривчастими курсами - у 10-12; 22-26; 30-32 тижні вагітності.

2. Мікрогранульований порошок магнію оксид, 535 мг, що відповідає 300 мг магнію і магнію оксиду легкого 403,0435,2 мг, що відповідає іонам магнію 243 мг. Препарати призначали з 10 тижнів протягом усієї вагітності по 1 таблетці 1 раз на добу.

Результати дослідження та їх обговорення. Результати профрілактичного застосування пероральних препаратів магнію показали високу есрективність, нешкідливість і гарну переносимість запропонованої терапії порівняно із загальноприйнятими підходами (протокол МО3). У групі вагітних, які використовували препарати магнію (I група), значно меншою була частота загрози переривання вагітності та плацентарної дисфункції. Ефрективність профілактики прееклампсії становила 96,0 \% у I групі і тільки 68,0 \% у групі пацієнток, яким профрілактика прееклампсії здійснювалась за протоколом (II група).

Висновки. Визначено, що пацієнтки із групи ризику розвитку прееклампсії потребують призначення препаратів магнію, корекції способу життя та харчування. Профрілактичний прийом препаратів магнію пацієнтками з групи ризику розвитку прееклампсії є високоефективним, нешкідливим і гарно переноситься. Ефективність профрілактики прееклампсії становить $96,0 \%$.

Ключові слова: магній; профілактика; лікування; прееклампсія; ускладнення.

ДИАГНОСТИКА И КОРРЕКЦИЯ МАГНИЕВОГО ДЕФИЦИТА У БЕРЕМЕННЫХ С ОТЯГОЩЕННЫМ ГИНЕКОЛОГИЧЕСКИМ АНАМНЕЗОМ

Цель исследования - выделение пациенток с клиническими признаками дефицита магния среди беременных из группы риска развития преэклампсии и изучение эфрфективности применения у них препаратов магния для профилактики преэклампсии.

Материалы и методы. Нами осуществлено обследование и комплексную пероральную магниевую профилактику позднего гестоза у 100 беременных (I группа) из группы риска возникновения данного осложнения беременности. Результаты сравнивали с данными наблюдения за 50-ю беременными (II группа) из группы риска возникновения преэклампсии, которым к профилактическому комплексу пероральные препараты магния не добавляли. Контрольную группу (КГ) составили 50 здоровых женщин с фризилогическим течением беременности. Наличие десрицита магния определяли по результатам изучения данных опроса, зафиксированных в разработанной нами анкете для исследования десицита магния у беременных. Магниевую монопрофилактику преэклампсии осуществляли такими препаратами:

1. Магния оксид легкий 342 мг и магния карбонат легкий 670 мг, что соответствует 365 мг ионов $\mathrm{Mg}^{++}$- по 1 шипучей таблетке в сутки прерывистыми курсами - в 10-12; 22-26; 30-32 недели беременности.

2. Микрогранулированный порошок магния оксид, 535 мг, что соответствует 300 мг магния и магния оксида легкого 403,0-435,2 мг, что соответствует ионам магния 243 мг. Препараты назначали с 10 недель в течение всей беременности по 1 таблетке 1 раз в сутки.

Результаты исследования и их обсуждение. Результаты профилактического применения пероральных препаратов магния показали высокую эффективность, безвредность и хорошую переносимость предложенной терапии по сравнению с общепринятыми подходами (протокол МО3). В группе беременных, которые принимали препараты магния (I группа), значительно меньшей была частота угрозы прерывания беременности и плацентарной дисфункции. Эффрективность профрилактики преэклампсии составляла 96,0% в I группе и только 68,0 \% в группе пациенток, которым профилактика преэклампсии осуществлялась по протоколу (II группа).

Выводы. Выявлено, что пациентки из группы риска развития преэклампсии нуждаются в назначении препаратов магния, коррекции образа жизни и питания. Профилактический прием препаратов магния пациентками из группы риска развития преэклампсии является высокоэффрективным, безвредным и хорошо переносится. Эффеективность профилактики преэклампсии составляет 96,0\%.

Ключевые слова: магний; просилактика; лечение; преэклампсия; осложнения. 


\section{DIAGNOSTICS AND CORRECTION OF MAGNESIUM DEFICIENCY IN PREGNANT WOMEN WITH BURDENED GYNECOLOGICAL ANAMNESIS}

The aim of the study - to find patients with clinical signs of magnesium deficiency among pregnant women at risk of developing preeclampsia and study the effectiveness of magnesium preparations use for the prevention of preeclampsia.

Materials and Methods. The examination and complex oral prophylaxis of late gestosis in 100 pregnant women (group I) from the risk group of this complication of pregnancy were provided. The results were compared with the data from the observation of 50 pregnant women (group II) from the risk group of preeclampsia, in whom we did not add magnesium to the prophylaxis complex. The control group (CG) was 50 healthy women with a physiological duration of pregnancy. The presence of magnesium deficiency was determined by the results of the study of survey data recorded in the questionnaire developed by us to study the deficiency of magnesium in pregnant women. Magnesium monoprophylaxis of preeclampsia was carried out with the following drugs:

1. Magnesium oxide, light $342 \mathrm{mg}$ and magnesium carbonate light $670 \mathrm{mg}$, which corresponds to $365 \mathrm{mg}$ of ions $\mathrm{Mg}++-1$ tablet per day with intermittent courses - 10-12; 22-26; 30-32 weeks of pregnancy.

2. Microgranular magnesium oxide powder, $535 \mathrm{mg}$, corresponding to $300 \mathrm{mg}$ of magnesium and magnesium oxide light 403.0-435.2 mg, which corresponds to $243 \mathrm{mg}$ of magnesium ions. Drugs were prescribed from 10 weeks throughout the pregnancy of 1 tablet once a day.

Results and Discussion. The results of the prophylactic use of oral magnesium preparations showed high efficacy, harmlessness and good tolerability of the proposed therapy, compared with generally accepted approaches (Ministry of Health protocol). In the group of pregnant women who used magnesium preparations (group I), the frequency of the threatened abortion and placental dysfunction was much lower. The effectiveness of the pre-eclampsia prevention was $96.0 \%$ in the group I and only $68.0 \%$ in the group of patients that prevented preeclampsia from the protocol (group II).

Conclusions. It is determined that patients from the risk group of preeclampsia require the administration of magnesium preparations, lifestyle and nutrition corrections. Preventive administration of magnesium preparations in patients at risk of developing preeclampsia is highly effective, harmless and well tolerated. The effectiveness of pre-eclampsia prevention is $96.0 \%$.

Key words: magnesium; prophylaxis; treatment; preeclampsia; complication.

ВстУп. Прееклампсія належить до найзагрозливіших ускладнень вагітності, частота якої не має тенденції до зниження (від 1,5 до 23,3 \% усіх вагітностей) і яка визначає показники материнської та дитячої патології і смертності [1, 2].

Враховуючи складність патогенетичних механізмів розвитку прееклампсії, труднощі у проведенні просрілактики та терапії, неефективність лікування середньої та тяжкої фрорм прееклампсії, актуальною є розробка профрілактичних заходів. Ефрективним шляхом профілактики прееклампсії $€$ своєчасне виявлення вагітних із фракторами ризику та субклінічними фрормами прееклампсії, наступна їхня адекватна корекція дасть змогу запобігти розвитку прееклампсії і в такий спосіб запобігти тяжким материнським та перинатальним ускладненням [3-5].

Провідне місце в етіопатогенезі прееклампсії належить дефіциту магнію. Під час вагітності спостерігається значне підвищення потреби в магнії (на 20-30 \%), лабораторно підтверджений нормальний рівень магнію в сироватці крові вагітних не виключає наявності внутрішньоклітинного десріциту і в 2/3 випадків супроводжується клінічними проявами десріциту магнію. Недостатність магнію призводить до збільшення концентрації альдостерону, затримки рідини в організмі, набряків. Виникає відносна гіперестрогенемія, яка призводить до гіперпродукції печінкою ангіотензину, який підвищує рівень альдостерону в крові та підвищує артеріальний тиск.

Патогенетичним підґрунтям можливості й необхідності застосування препаратів магнію для корекції його дефіциту, а також для профрілактики прееклампсії є біорегуляторні механізми дії цього елемента в організмі людини. Механізм дії магнію можна пояснити його зв'язуванням із такими молекулами, як нуклеотиди (АТФ, ДНК, РНК), протеїни (ферменти), і з низькомолекулярними сполуками (органічні кислоти). Багато з цих молекул виконує фрункцію стимуляторів у процесах обміну речовин, і їхні регуляторні властивості активуються лише у разі поєднання з магні- єм. У рамках біохімічних процесів даний мікроелемент необхідний для енергообміну, як антагоніст кальцію, для стабілізації молекул і регуляції обміну речовин.

Есректами дії магнію $є$ нормалізація синтезу білка та оксиду азоту, зниження тонусу матки, вазодилатація, покращення кровоплину в судинах плаценти, зниження агрегації тромбоцитів (підвищення активності простациклінів і зниження активності тромбоксанів А2). Усе це сприяє запобіганню розвитку диссрункції ендотелію та її наслідків (гіперкоагуляція, гестоз та плацентарна дисфункція), адекватному функціонуванню ЦНС та периферичної нервової системи, а також нормалізації судинного тонусу, підвищенню стійкості тканин плода до гіпоксії, знижує частоту синдрому затримки розвитку плода. Відомо, що на тлі магнезіальної терапії знижується ризик крововиливів у тканину головного мозку в дитини шляхом реалізації механізму енергетичної підтримки клітин ЦНС, знижується частота синдрому раптової смерті новонароджених, підвищується стійкість тканин плода до гіпоксії, у тому числі після пологів [6-8].

C. Bullarbo et al. (2013) [9] довели, що за рахунок есректу м'язової релаксації магній запобігає судомам і як антагоніст кальцію магній знижує підвищений і нормалізує АТ під час вагітності.

Діагностичні тести для виявлення магнієвого дефріциту не показові, оскільки цей елемент міститься переважно в клітинах (у сироватці крові лише 0,3 \% від усіх запасів) i нормальний рівень магніюу плазмі крові не виключає наявності внутрішньоклітинного дефіциту. Тому слід більшу увагу приділяти клінічним ознакам десріциту цього елемента. Основними ознаками дефіциту магнію в організмі матері є стан підвищеної нервово-психічної збудливості: дратівливість, схильність до стресів, прояви тривожності, депресивності, безсоння, астенія. Про десріцит магнію свідчать також ознаки підвищеної м'язової збудливості: біль у попереку, м'язові судоми, підвищення тонусу матки, іноді аж до викидня, біль під час сечовипускання. 
МЕТА ДОсЛІДЖЕННЯ - виокремлення пацієнток із клінічними ознаками дефріциту магнію серед вагітних із групи ризику розвитку прееклампсії і вивчення ефективності застосування в них препаратів магнію для профілактики прееклампсії.

МАТЕРІАЛИ ТА МЕТОДИ. Нами здійснені обстеження і комплексна пероральна магнієва профрілактика пізнього гестозу в 100 вагітних (I група) із групи ризику виникнення цього ускладнення вагітності. Визначення фракторів ризику і базова профрілактика проводилися згідно 3 протоколом «Гіпертензивні розлади під час вагітності», наказ № 676 МО3 України [10]. Результати порівнювали із даними спостереження за 50-ма вагітними (II група) 3 групи ризику виникнення прееклампсії, яким до профрілактичного комплексу пероральні препарати магнію не додавали. Контрольну групу (КГ) склали 50 здорових жінок із фрізіологічним перебігом вагітності.

Наявність дефріциту магнію визначали за результатами вивчення даних опитування, зафіксованих у розробленій нами анкеті для дослідження десріциту магнію у вагітних. Анкета містила дані про наявність у пацієнтки ознак соматичної патології, патології нервової системи, обтяженого акушерсько-гінекологічного анамнезу, особливостей харчування, способу життя і загального самопочуття, ускладненого перебігу даної вагітності тощо. Анкету розроблено з використанням матеріалів анкет, запропонованих О. А. Громовою та О. А. Лімановою (РСЦ Інституту мікроелементів ЮНЕСКО, 2014).

Результати тесту оцінювали в балах: ознака відсутня - 0 балів; з'являється періодично, легкий перебіг - 1 бал; присутня постійно, тяжкий перебіг - 2 бали. Відповідно до отриманих результатів пацієнток розподілили на групи: 31-132 бали - значний десіцит магнію, що потребує екстреної магнезіотерапії, корекції способу життя та харчування; 11-30 балів - помірний десріцит, що потребує призначення препаратів магнію, корекції способу життя та харчування; 5-10 балів - межовий десріцит магнію, потребує кореції дієти та способу життя.

Магнієву монопрофрілактику прееклампсії здійснювали такими препаратами:

1. Магнію оксид легкий 342 мг і магнію карбонат легкий 670 мг, що відповідає 365 мг іонів $\mathrm{Mg}^{++}$- по 1 шипучій таблетці на добу переривчастими курсами - у 10-12; 22-26; 30-32 тижні вагітності.

2. Мікрогранульований порошок магнію оксид, 535 мг, що відповідає 300 мг магнію і магнію оксиду легкого 403,0-435,2 мг, що відповідає іонам магнію 243 мг. Препарати призначали з 10 тижнів протягом усієї вагітності по 1 таблетці 1 раз на добу.
РЕЗУЛЬТАТИ ДОСЛІДЖЕННЯ ТА ЇХ ОБГОВОРЕННЯ.

За результатами тестування зі 100 обстежених пацієнток із групи ризику розвитку прееклампсії 76 (76,0 \%) були зараховані до групи значного десріциту магнію, що потребує екстреної магнезіотерапії, корекції способу життя та харчування (від 31 до 132 балів), а 24 вагітні потрапили в групу з помірним дефіцитом, що потребує призначення препаратів магнію, корекції способу життя та харчування (11-30 балів).

Результати профрілактичного застосування пероральних препаратів магнію показали високу ефективність, нешкідливість і гарну переносимість запропонованої терапії порівняно із загальноприйнятими підходами (протокол МО3).

Отримані нами результати наведені в таблиці 1. Аналіз наведених даних доводить, що в групі вагітних, які використовували препарати магнію (I група), значно меншою була частота загрози переривання вагітності та плацентарної дисфрункції. Ефеективність профрілактики прееклампсії становила 96,0 \% у I групі і тільки 68,0 \% у групі пацієнток, яким профрілактика прееклампсії здійснювалась за протоколом (II група). Відсотки ускладнень у пологах та частота кесаревого розтину були в 2 рази вищими в групі жінок, які не отримували препарати магнію для профрілактики та лікування прееклампсії (табл. 1).

Результати спостереження за новонародженими пацієнток обох груп показали, що новонароджені у породіль, які отримували препарати магнію з метою профрілактики прееклампсії, мали вищу оцінку за шкалою Апгар. Так, на 5-й хвилині оцінку в 7 балів і нижче мали 22,0 \% дітей від матерів з групи, яка отримувала лікування за протоколом.

У групі пацієнток, які з метою проорілактики прееклампсії приймали препарати магнію, цей показник склав 9,0 \%, що в 2,5 раза менше порівняно з групою пацієнток, яким не вводили до профрілактичних засобів препаратів магнію. Захворюваність новонароджених і перинатальні ураження нервової системи також були значно вищими в групі пацієнток без магнієвої профрілактики прееклампсії (табл. 2).

висновкИ. Отже, отримані нами результати застосування пероральних препаратів магнію для профрілактики прееклампсії дозволяють дійти таких висновків:

1. Деоріцит магнію виявлено у 100,0 \% пацієнток із групи ризику розвитку прееклампсії. Значний десріцит встановлено у 76 (76,0 \%) пацієнток і помірний - у 24,0\% жінок. Тобто пацієнтки із групи ризику розвитку прееклампсії потребують екстреної магнезіотерапії (31-132 бали), призначення препаратів магнію, корекції способу життя та харчування (11-30 балів).

Таблиця 1. Частота ускладнень вагітності та пологів (P士m)

\begin{tabular}{|l|c|c|c|c|c|}
\hline \multicolumn{1}{|c|}{$\begin{array}{c}\text { Групи } \\
\text { пацієнток }\end{array}$} & $\begin{array}{c}\text { Загроза переривання } \\
\text { вагітності }\end{array}$ & $\begin{array}{c}\text { Диссрункція } \\
\text { плаценти }\end{array}$ & Прееклампсія & $\begin{array}{c}\text { Ускладнені } \\
\text { пологи }\end{array}$ & Кесарів розтин \\
\hline КГ $(\mathrm{n}=50)$ & $12,0 \pm 4,6^{*}$ & $6,0 \pm 3,4^{*}$ & - & $8,0 \pm 3,8^{*}$ & $8,0 \pm 3,8^{*}$ \\
\hline $\begin{array}{l}\text { I група } \\
(\mathrm{n}=100)\end{array}$ & $17,0 \pm 3,8^{\Delta}$ & $11,0 \pm 3,1^{\Delta}$ & $4,0 \pm 2,0^{\Delta}$ & $12,0 \pm 3,2^{\Delta}$ & $15,0 \pm 3,6^{\Delta}$ \\
\hline $\begin{array}{l}\text { II група } \\
(\mathrm{n}=50)\end{array}$ & $44,0 \pm 7,0^{* *}$ & $32,0 \pm 6,7^{* *}$ & $32,0 \pm 6,7$ & $30,0 \pm 6,5^{* *}$ & $32,0 \pm 6,7^{* *}$ \\
\hline
\end{tabular}

Примітка. * - p<0,05 між показниками у КГ та I групі; ** - p<0,05 між показниками у КГ та II групі; $\Delta-p<0,05$ між першою і другою групами. 
Таблиця 2. Стан новонароджених у досліджених пацієнток (P士m)

\begin{tabular}{|l|c|c|c||}
\hline \multicolumn{1}{|c|}{ Новонароджені з груп } & Оцінка за Апгар 7 балів і менше & Захворюваність & Ураження НС \\
\hline КГ $(\mathrm{n}=50)$ & $2,0 \pm 2,0$ & $2,0 \pm 2,0$ & - \\
\hline I група $(\mathrm{n}=100)$ & $9,0 \pm 2,9^{\star}$ & $13,0 \pm 3,4^{\star}$ & $7,0 \pm 2,6$ \\
\hline II група $(\mathrm{n}=50)$ & $22,0 \pm 5,9^{\star \star}$ & $20,0 \pm 5,7^{\star \star}$ & $18,0 \pm 5,4$ \\
\hline
\end{tabular}

Примітка. * - p<0,05 між показниками у КГ та I групі; ** - p<0,05 між показниками у КГ та II групі; $\Delta-p<0,05$ між першою і другою групами.

2. Профрілактичний прийом препаратів магнію пацієнтками з групи ризику розвитку прееклампсії $€$ високоефективним, нешкідливим і гарно переноситься. Ефективність профрілактики прееклампсії становить 96,0 \%.

3. До позитивних ефректів профрілактичного прийому препаратів магнію слід зарахувати значне зменшення частоти ускладнень вагітності і пологів, зниження частоти кесаревого розтину.

4. Перинатальні наслідки більш сприятливі для новонароджених, матері яких отримували профрілактику прееклампсії препаратами магнію.

5. Вважаємо за доцільне використання препаратів магнію як базових препаратів у комплексі із засобами, що поліпшують мікроциркуляцію (аспірин, курантил, тівортін та ін.), що забезпечує посилення есрективності перелічених препаратів у просрілактиці прееклампсії.

6. Позитивні ефекти від застосування препаратів магнію пов'язані не лише зі спазмолітичними властивостями, а також із сприятливим впливом на психоемоційний стан жінки, що послаблює негативні наслідки стресових ситуацій.

ПЕРСПЕКТИВИ ПОДАЛЬШИХ ДОСЛІДЖЕНЬ. ВВажаємо за доцільне подальше вивчення концентрацій магнію у пацієнток з різними видами акушерських ускладнень та соматичної патології. Результати досліджень дозволять обґрунтувати необхідність застосування препаратів магнію для профілактики та лікування акушерських патологій.

\section{СПИСОК ЛІТЕРАТУРИ}

1. Гестозы. Руководство для врачей / Б. М. Венцковский, В. Н. Запорожан, А. Я. Сенчук, Б. Г. Скачко. - М. : Медицинское инорормационное агентство, 2005. - 312 с

2. Современный взгляд на проблему гестоза / П. Н. Веропотвелян, Н. П. Веропотвелян, Е. П. Смородская, А. Т. Лазаренко // Медицинские аспекты здоровья женщины. - 2011. - № 6 (46). - С. 43-52.

3. Магній. Біологічна роль і застосування в акушерстві та гінекології : навч. посіб. / за ред. проф. А. Я. Сенчука. - К. Видавництво «Фенікс», 2018. - 104 с.

4. Ефективність препарату Біолектра Магнезіум Дірект при лікувально-профрілактичних заходах у вагітних з прееклампсією / Г. І. Резніченко, Ю.М.Бессарабов, В. Ю. Потебня, К. І. Коваленко // Здоровье женщины. - 2015 - № 6 (102). -С. 12-16.

5. Радзинский В. Е. Акушерская агрессия / В. Е. Радзинский. - М. : Изд-во журнала Status Presens, 2011. - 688 с.

\section{REFERENCES}

1. Ventskovskiy, B.M., Zaporozhan, V.N., Senchuk, A.Ya., \& Skachko, B.G. (2005). Gestozy. Rukovodstvo dlya vrachey [Gestosis. A guide for doctors]. Moscow: Meditsinskoye informatsionnoye agentstvo [in Russian].

2. Veropotvelyan, P.N., Veropotvelyan, Ye.P., Smorodskaya, A.T., \& Lazarenko, N.P. (2011). Sovremennyy vzglyad na problemu gestoza [Modern view on the problem of preeclampsia]. Meditsinskiye aspekty zdorovya zhenshchiny - Medical Aspects of Woman's Health, 6 (46), 43-52 [in Russian].

3. Senchuk, A.Ya. (Ed.). (2018). Mahnii. Biolohichna rol $i$ zastosuvannia $v$ akusherstvi ta hinekolohii: navchalnyi posibnyk [Biological role and application in obstetrics and gynecology: textbook]. Kyiv: Vydavnytstvo "Feniks" [in Ukrainian].
6. Asemi S. Magnesium supplementation affects metabolic status and pregnancy outcomes in gestational diabetes: a randomized, double-blind, placebo-controlled trial / S. Asemi // Am. J. Clin. Nutr. - 2015. - Vol. 102 (1). - P. 222-229.

7. Grober U. Magnesium in prevention and therapy / U. Grober, J. Schmidt, K. Kisters // Nutrients. - 2015. - Vol. 7 (9). - P. 8199-226.

8. Shechter M. Comparison of magnesium status using X-ray dispersion analysis following magnesium oxid and magnesium citrate treatment of healthy subjects / M. Shechter, T. Saad, A. Shechter // Magnes. Res. - 2012. - Vol. 25 (1). - P. 28-39.

9. Bullarbo C. Magnesium supplementation to prevent high blood pressure in pregnancy: a randomised placebo control trial / C. Bullarbo // Arch. Gynecol. Obstet. - 2013. - Vol. 288 (6). - P. 1269-1274.

10. Про затвердження клінічних протоколів з акушерської та гінекологічної допомоги : наказ МОЗ України від 31.12.2004 p. № 676.

4. Reznichenko, H.I., Bessarabov, Yu.M., Potebnia, V.Yu., \& Kovalenko, K.I. (2015). Efektyvnist preparatu Biolektra Mahnezium Direkt pry likuvalno-profilaktychnykh zakhodakh u vahitnykh z preeklampsiieiu [Efficiency of Biolectra Magnesium Direct drug in treatment and prophylactic measures in pregnant women with preeclampsia]. Zdorovye zhenshchiny - Health of a Woman, 6 (102), 12-16 [in Russian].

5. Radzinskiy, V.Ye. (2011). Akusherskaya agressiya [Obstetric aggression]. Moscow: Izd-vo zhurnala Status Presens [in Russian].

6. Asemi, Z., Karamali, M., Jamilian, M., Foroozanfard, F., Bahmani, F., Heidarzadeh, Z., ... \& Esmaillzadeh, A. (2015). Magnesium supplementation affects metabolic status and 
pregnancy outcomes in gestational diabetes: a randomized, double-blind, placebo-controlled trial. Am. J. Clin. Nutr., 102 (1), 222-229.

7. Grober, U., Schmidt, J., \& Kisters, K. (2015). Magnesium in prevention and therapy. Nutrients, 7 (9), 8199-8226.

8. Shechter, M., Saad, T., Shechter, A., Koren-Morag, N., Silver, B.B., \& Matetzky, S. (2012). Comparison of magnesium status using $X$-ray dispersion analysis following magnesium oxid and magnesium citrate treatment of healthy subjects. Magnes. Res., 25 (1), 28-39.
9. Bullarbo, C. (2013). Magnesium supplementation to prevent high blood pressure in pregnancy: a randomised placebo control trial. Arch. Gynecol. Obstet., 288 (6), 1269-1274.

10. Nakaz MOZ Ukrainy vid 31. 12. 2004 r. № 676 "Pro zatverdzennia klinichnykh protokoliv z akusherskoi ta hinekolohichnoi dopomohy" [Order of the Ministry of Health of Ukraine dated December 31, 2004 No. 676 "On Approval of Clinical Protocols on Obstetric and Gynecological Aid"]. [in Ukrainian].

Отримано 07.02.19 